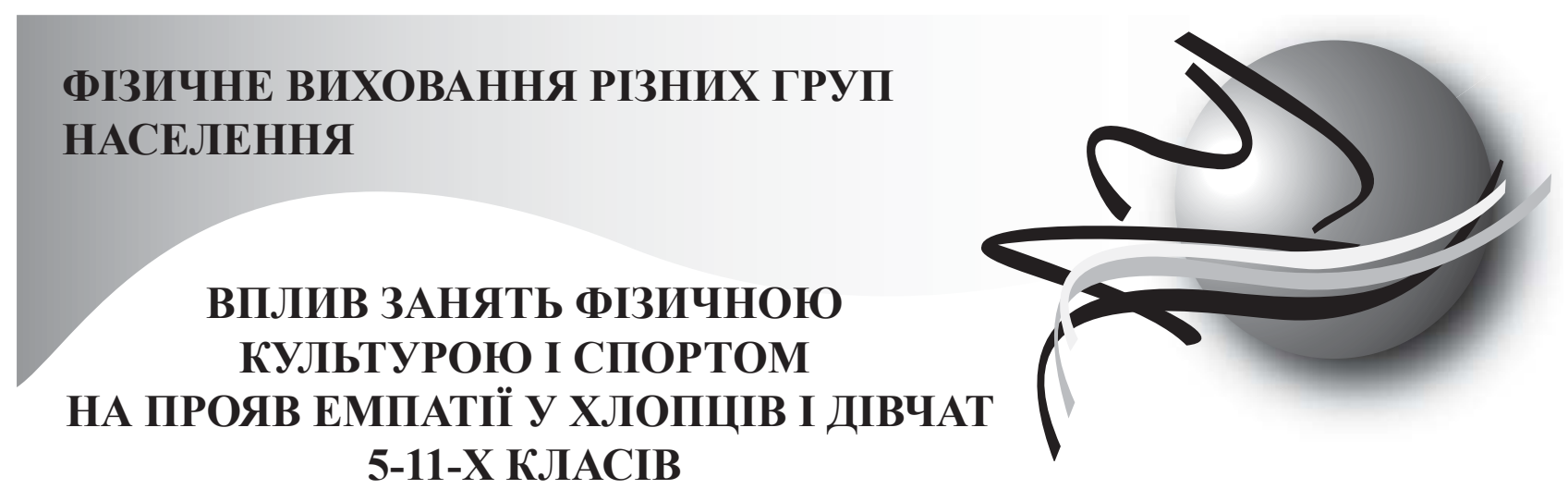

Круцевич Тетяна, Марченко Оксана, Холодова Ольга

Національний університет фізичного виховання і спорту України

\title{
DOI: 10.32540/2071-1476-2021-2-061
}

\section{Annotation}

Introduction and study purpose. Introduction and purpose of the study. The presented article provides a theoretical analysis of literary sources on the problem of studying empathy in the physical education of young people. The purpose of the article is to determine the influence of physical culture and sports on the manifestation of empathy in schoolchildren of grades 5-11.

Material and methods. The results of the study are based on the materials of questionnaires and testing of 638 students of 5-11 forms (303 boys and 335 girls) of secondary education institutions. A set of methods was used to solve the tasks: analysis, generalization and systematization of scientific and methodological literature; questionnaire, psychological and diagnostic testing, test questionnaire S. Bem "Masculinity - femininity", generally accepted methods of mathematical statistics.

Results. The research results are based on the materials of questioning and testing of 638 schoolchildren of 5-11 grades ( 303 boys and 335 girls) of secondary schools. To solve the set tasks, a set of methods was used: analysis, generalization and systematization of scientific and methodological literature data; questioning, to study the level of empathy of schoolchildren, the methodology of I.M. Yusupov, the generally accepted methods of mathematical statistics was used.

Summary. Physical education and sports have a certain impact on the level of empathy formation among schoolchildren. At the same time, girls develop not only leadership and strong-willed character traits, but also such qualities as: sympathy, a desire to help, generosity and responsiveness. The low level of empathy of young men who go in for sports is confirmed in the choice of motives for going in for physical culture and sports, since the specificity of sports is to defeat an opponent and is an integral part of victory in competitions.

Key words: physical education, boys, girls, motivation, students, empathy

\footnotetext{
Анотація

Вступ і мета дослідження. У представленій статті проведено теоретичний аналіз літературних джерел 3 проблеми дослідження емпатії у фізичному вихованні.

Метою статті $є$ визначення впливу занять фізичною культурою і спортом на прояв емпатії у школярів 5-11-х класів.

Матеріал і методи. Результати дослідження засновані на матеріалах анкетування та тестування 638 школярів 5-11 класів (303 юнака та 335 дівчат) 33СО. Для розв’язання поставлених завдань використовувався комплекс методів: аналіз, узагальнення та систематизація даних науково-методичної літератури; анкетування, для вивчення загального рівня емпатії школярів була використана методика І. М. Юсупова. загальноприйняті методи математичної статистики.
}

(c) Круцевич Т., Марченко О.,

Холодова О., 2021 
Результати. Узагальнені дані засвідчують, що у віковій групі 11-13 років, хлопці та дівчата у переважній кількості мають середній (нормальний) та високий рівні емпатії. Високий рівень емпатії мають більше дівчат, ніж хлопців. Юнаки і дівчата 14-15 років, які займаються спортом, у своїй быльшості мають середній рівень емпатії, проте з віком дівчата-спортсменки стають більш емпатійними, на відміну від юнаків. Серед дівчат, які займаються спортивною діяльністю, не виявлено осіб з низьким рівнем емпатії, натомість кількість юнаків із низьким рівнем емпатії з віком зростає.

Висновки. Заняття фізичною культурою і спортом мають певний вплив на рівень формування емпатії у школярів, про що свідчать отримані нами у перебігу дослідження результати. Виявлено, що, заняття спортом формують у дівчат не тільки лідерські та вольові якості особистості, а також співчуття, бажання допомоги, великодушність та чуйність. Низький рівень емпатії юнаків, які займаються спортом знаходить своє підтвердження у виявлені мотивів щодо спортивної діяльності, бо специфіка спорту полягає в перемозі над суперником, що є невід’ємним складником перемоги у змаганнях.

Ключові слова: фізична культура і спорт, школярі, юнаки, дівчата, мотивація, емпатія

\section{Аннотация}

Введение и цель исследования. В представленной статье проведен теоретический анализ литературных источников по проблеме исследования эмпатии в физическом воспитании молодежи. Целью статьи является определение влияния занятий физической культурой и спортом на проявление эмпатии у школьников 5-11-х классов.

Материал и методы. Результаты исследования основаны на материалах анкетирования и тестирования 638 школьников 5-11 классов (303 юноши и 335 девушек) общеобразовательных школ. Для решения поставленных задач использовался комплекс методов: анализ, обобщение и систематизация данных научнометодической литературы; анкетирование, для изучения уровня эмпатии школьников была использована методика И. М. Юсупова, общепринятые методы математической статистики.

Результаты. Обобщенные данные свидетельствуют, что в возрастной группе 11-13 лет мальчики и девочки в большинстве имеют средний (нормальный) и высокий уровни эмпатии. У девочек уровень эмпатии выше, чем у мальчиков. Юноши и девушки 14-15 лет, которые занимаются спортом имеют средний уровень эмпатии, однако с возрастом девушки-спортсменки становятся более емпатийными. Среди них не обнаружено респондентов с низким уровнем эмпатии.

Выводы. Занятия физической культурой и спортом оказывают определенное влияние на уровень формирования эмпатии школьников. При этом, у девушек формируются не только лидерские и волевые черты характера, но и такие качества как сочувствие, желание помочь, великодушие и отзывчивость. Низкий уровень эмпатии юношей, которые занимаются спортом, находит свое подтверждение в выборе мотивов к занятиям физической культурой и спортом, так как специфика спорта заключается в победе над соперником и является неотъемлемой составляющей победы в соревнованиях.

Ключевые слова: физическая культура и спорт, юноши, девушки, мотивация, школьники, эмпатия

Вступ. Сьогодні, коли Україна формується як розвинута, демократична, правова країна світу, послідовно наближає критерії та орієнтири національного розвитку до стандартів, прийнятих в країнах Європейського Союзу, не можна недооцінювати стан здоров'я, соціальне самопочуття населення в цілому і молоді зокрема. Якісний стан фізичного та духовного здоров'я молоді є показником цивілізованості держави $[1$,$] .$

Однією 3 важливих соціальних проблем, 3 якою сьогодні зустрічаються більшість країн
Європи, - фізичне, психічне та духовно-моральне вдосконалення молодого покоління [29]. За даними дослідників, останні 20-25 років знаменуються широким розповсюдженням серед учнівської молоді різноманітних психічних розладів. Частіше за все вони формуються в момент вступу до школи, при переході до середніх класів та у старшокласників у зв'язку з підвищеним навчальних навантаженням. Кількість абсолютно здорових у психічному відношенні школярів знижується та складає у випускних класах всього 10-15 \% [29 С. 7]. Пробле- ма такого негативного соціального явища, як булінг, актуальна не лише для українського суспільства, а й для всього світу, та є одним із найбільш розповсюджених негативних соціальних явищ серед підлітків.

Важливим значенням у вирішенні таких питань може бути створення ефективної системи виховання учнівської молоді. Йдеться про створення таких умов, які б допомогли молоді визначити мотиви, ідеали, цілі, способи їх досягнення і види діяльності на основі самореалізації та самовдосконалення.

(C) Круцевич Т., Марченко О., Холодова О., 2021 
Загальновідомо, що фізична культура і спорт виступають не тільки як засіб покращення фізичного розвитку та зміцнення здоров'я, але й у поєднанні 3 іншими засобами виховання, сприяють всебічному розвитку особистості, впливаючи на формування характеру людини, тобто тих особливостей особистості, які відбиваються на вчинках і відносинах із іншими людьми та зовнішнім світом. Це сфера, в якій у різних формах знаходяться прояви основних творчих цінностей $[14,15,17]$.

Аспекти розвитку особистості висвітлювалися в роботах відомих вітчизняних психологів та педагогів (К.А. АбульхановаСлавська, М.Й. Боришевський, Д.Б. Ельконін, О.В. Запорожець, Г.С. Костюк, С.Д. Максименко, H.I. Непомняща, B.А. Сухомлинський, та інші), які стали методологічним та теоретичним підгрунтям багатьох досліджень цієї проблеми. Так, спираючись на дослідження науковців, саме успішне виконання завдань фізичної підготовки і спортивного тренування, навчання, виховання й управління зумовлюється вмінням опертися на положення індивідуального підходу, що полягають у знанні індивідуальних особливостей особистості учня [17, 20, 22].

Розвиток особистості через заняття фізичною культурою i спортом розглядається у наукових працях вітчизняних та зарубіжних вчених (Ю.М. Ніколаєв, 2003; Н.М. Візітей, 2005; В.I. Столяров., 2015; Т. Ю. Круцевич., 2010-2020; Н.В. Москаленко, 2010, 2018; Н.Э. Пангелова, 2014; Л.І. Лубишева, 2004; В.В. Приходько, 2004, 2008; О.Ю. Марченко, 2010) ) [7, 14, 15, 21, 22, 27].

Дослідженю мотивів та інтересів школярів середньої та старшої школи до занять фізичною культурою і спортом, їх зміна в процесі вікового розвитку, особливості прояву в осіб різної статі, 3 різними властивостями ВНД і в залежності від регіону проживання присвячені роботи Г.В. Безверхньої (2004). Ціннісні орієнтації у сфері фізичної культури серед учнів старшої школи були досліджені М.М. Саїнчуком (2011)

Зарубіжні й вітчизняні педагоги все частіше висловлюються за ширше використання підходів iз формування емпатії в сфері освіти $[6,31,35]$, розробляють нові компетентності, які, якщо і не прямо, то опосередковано стосуються емпатії. В українському освітньому просторі «емпатійна» проблематика обділена належною увагою і цей напрям, судячи із нечисленних публікацій $[5,19,26]$, лише на стадії зародження [27].

Досліджуючи емпатію у фізичному вихованні, зарубіжні науковці вважають за потрібне формування емпатійних навичок у процесі фізичного виховання та $[25,27,30,33,37]$.

Нас зацікавили дослідження емпатійної спрямованості, але ми не розглядаємо емпатію в контексті морального або етичного аспектів, а розуміємо як певний прояв в деяких сферах життєдіяльності людини. До того ж, як показує дослідження М.М. Саїнчука [26] суспільство потребує тверезого розуміння фізично досконалих людей. Саме від цих кроків у майбутньому і залежатиме становлення повноцінно сформованої людини [5].

Аналіз наукової літератури засвідчує різноманітне тлумачення терміна «емпатія» серед науковців. Серйозні дослідження емпатії почалися в 19 ст. в Свропі. Поняття «емпатія» ввів у психологію Е. Тітченер у 1909 році. Цей термін означав розгляд ситуації з точки зору співрозмовника, емоційне відчуття, розуміння, сприйняття його актуального емоційного стану [8]. В психології терміном «емпатія» описуються різні психологічні стани $[3,8,11,25]$.

Також емпатія визначає інди- відуальну чутливість спортсмена до стресу змагання. Як риса особистості, вона певною мірою характеризує схильність досліджуваних до співпереживання та складає ядро комунікації. У комунікативній діяльності емпатія сприяє збалансованості міжособистісних відносин, робить поведінку людини соціально обумовленою[5, 8, 19] .

Відомо, що розвиток вищих форм емпатії та остаточне становлення емпатійності, як інтегральної особистісної якості, відбувається в юнацькому віці (Л.П. Журавльова) [8]. У цей же період значною мірою розширюється коло міжособистісних контактів, змінюються їх форми та види, спрямованість і значущість, набувають змін якісні характеристики [11].

Апелюючи до авторитетних наукових джерел, зазначимо, що дані зарубіжних досліджень, спрямованих на вивчення емпатії підлітків та юнаків, свідчать про глибокі зв'язки між емпатійністю та етичною поведінкою. Високо емпатійні діти в міжособистісній взаємодії власні невдачі схильні пояснювати внутрішніми причинами, тоді як діти 3 низькими показниками емпатії дають їм екстремальну оцінку [8]. У нашому дослідженні ми розглядаємо емпатію як властивість, котра проявляється в розумінні внутрішнього світу іншої людини, емоційному залученні в іiі життя. Усі ці трансформації надають взаєминам підлітків ще більшої гостроти, впливають на формування їхньої особистості, отже, роблять підлітковий вік сприятливим для дослідження впливу занять спортом на формування емпатії. Емпатійні стани співчуття, співпереживання, які багаторазово повторюються, стають властивістю особистості. Саме в дослідженнях, які проводяться в підлітковому та юнацькому середовищі, вперше починають виявлятися статеві відмінності у 
ставленні до різних об'єктів емпатії. Проте сьогодні, на жаль, немає грунтовних комплексних досліджень впливу занять фізичною культурою і спортом на прояв емпатії. Узагальнення та систематизація існуючих результатів досліджень із даної проблеми свідчить, що питання впливу фізичної культури і спорту на прояв емпатії у підлітків залишається до кінця не дослідженим. Вищевикладене підтверджує актуальність проблеми, детермінує іiі вибір як теми наукового дослідження і $є$ підгрунтям окремого дослідження зазначеної проблеми, яка має теоретичну, практичну й соціальну значущість.

Мета статті - визначити вплив занять фізичною культурою і спортом на прояв емпатії у школярів 5-11-х класів.

Зв'язок роботи 3 науковими планами, темами. Наукове дослідження виконано відповідно до тематичного плану наукових досліджень та розробок, що виконуються за рахунок коштів державного бюджету $\mathrm{MOH}$ на 2016-2019 pр. за темою «Історичні та організаційно - методичні засади формування гендерного підходу у фізичному вихованні дітей, підлітків і молоді» шифр 1.2Ф. (№ державної реєстрації 0117U002386) та у межах науково-дослідної роботи Зведеному плану НДР НУФВСУ на 20162020 p.p. за темою № 3.1 «Теоретико-методичні основи вдосконалення програмно-нормативних засад фізичної підготовки дітей, підлітків і молоді» (№ державної реєстрації 0111U001626).

Матеріал і методи. Результати дослідження засновані на матеріалах анкетування та тестування 638 школярів 5-11 класів (303 юнака та 335 дівчат) 33СО м. Полтави. Процедура наукових досліджень проводилася відповідно до етичних стандартів відповідального комітету $з$ прав людини, за погодженням управління освіти Полтавського міськвиконкому та письмової згоди директорів шкіл та батьків респондентів, що підтверджується відповідними документами.

Результати досліджуваних стратифікувались відповідно віковим періодам фізіологічного розвитку дітей і біологічної статі. Достовірність різниці між окремими результатами вираховувалась на рівні надійності $\mathrm{p}<0,05$ до $\mathrm{p}<0,01$, що свідчить про можливість їх врахування при розробці практичних рекомендацій, а також для подальших інтерпретацій.

Для розв'язання поставлених завдань використовувався комплекс методів:

теоретичні (аналіз, порівняння, узагальнення, систематизація, теоретичне моделювання) проводились із метою узагальнення досвіду науковців, які займаються вивченням сучасних підходів до розвитку та вдосконаленню системи фізичного виховання;

педагогічні (спостереження із застосування інструментальних методик, експеримент) проводились із метою вивчення умов організації фізичного виховання у закладах загальної середньої освіти, поведінки школярів на заняттях фізичною культурою, їхньої взаємодії з учителем фізичної культури;

соціологічні (неформалізовані бесіди, опитування, анкетування) проводились 3 метою визначення спортивних інтересів, уподобань, мотивів до занять руховою активністю у навчальний та поза навчальний час;

психолого-діагностичні (тестопитувальник I.M. Юсупова,), що дозволило визначити рівень прояву емпатії школярів.

загальноприйняті методи математичної статистики 3 розрахунком середніх арифметичних величин (х), середнього квадратичного відхилення (S); розраховувався коефіцієнт кореляції рангів Спірмена.

Усі розрахунки виконувалися в програмі SPSS 17.0. Всі дані оброблялись на персональному комп'ютері з використанням пакету стандартних програм (Excel - 2007; Statistica - 10.0).

Результати. Центральне соціально-психологічне новоутворення юнацького віку - розвиток «Я-концепції». Юнацький вік I.M. Юсупов характеризує як період маргінальної соціалізації. Підліток перебуває нібито в проміжному, межовому положенні між різними соціальними і віковими групами, що накладає певний відбиток на психіку людини і може виражатися в підвищеній тривожності, неконтактності в спілкуванні, агресивності, егоцентричності, а також виявлятися в реакціях емансипації, компенсації, групування 3 однолітками тощо [30].

Для вирішення завдань дослідження, на першому етапі проведено анкетування респондентів. Була застосована анкета «Визначення мотивів та інтересів школярів у галузі фізичної культури і спорту». Анкетування використовувалося для одержання інформації про мотивацію до занять фізичною культурою і спортом школярів та їх інтерес до видів спорту.

Серед обстежуваного контингенту займаються спортом 126 респондентів (97 юнаків та 29 дівчат) - баскетболом, волейболом, боротьбою, атлетичною гімнастикою та тхеквондо. Інші респонденти відвідують навчальні заняття $з$ фізичного виховання у школі та займаються додатково спортивно-оздоровчою діяльністю.

За результатами анкетування виявлено, що в основі потребо-мотиваційної сфери фізичної культури і спорту хлопців і дівчат існують як спільні, так суттєво відмінні пріоритети. Хлопці та юнаки більшою мірою обирають силові види спорту - тхеквондо, боротьбу та футбол. Дівчата надають перевагу різновидам фітнесу,

(C) Круцевич Т., Марченко О., Холодова О., 2021 


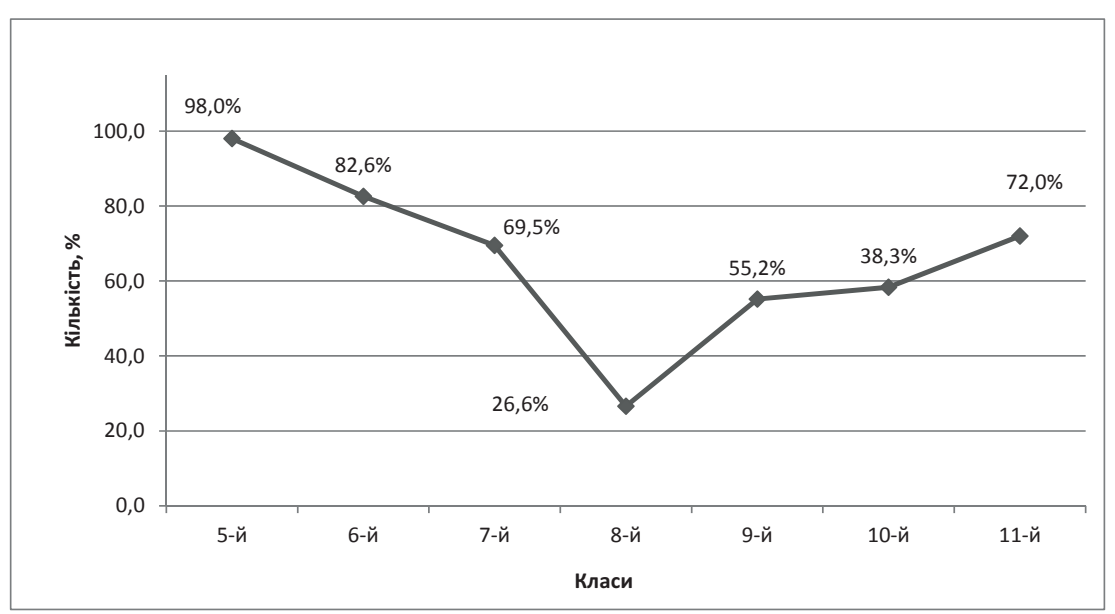

\section{Рис. 1. Кількість учнів 5-11 класів, які займаються спортивно-оздоровчою діяльністю (хлопці), \%.}

спортивним танцям і волейболу. 3 5-го по 11-й класи через різні причини кількість школярів, які займаються спортивною діяльністю, суттєво зменшується (рис.1). Якщо у 5-му класі займаються фізкультурно-спортивною діяльністю 98 \% хлопців, то серед восьмикласників їх залишається $26,6 \%$ Так само й у дівчат, із 5-го по 7-й клас простежено зниження інтересу до занять спортом: відповідно його активно виявляють 75 \% п'ятикласниць і тільки $33 \%$ учениць 7-го класу. 3 8-го класу кількість, які займаються спортом та фізичною активністю, підвищується до $42 \%$. Як і в юнаків, простежено позитивну динаміку: $53 \%$ старшокласниць займаються спортивною діяльністю у позанавчальний час (рис.2).

У ранньому юнацькому віці (15-17 років) уже складаються визначені відношення 3 навколишнім світом. Шкільний вік сенситивний для формування ціннісних орієнтацій. Стають нагальними потреби старшокласників у саморозвитку, самовдосконаленні та самореалізації, що $€$ показником особистісної зрілості та одночасно й умовою іiі досягнення. Тому, починаючи чи продовжуючи заняття спортом у

(C) Круцевич Т., Марченко О., Холодова О., 2021 цьому віці, школярі стають більш мотивованими та цілеспрямованими. Молода людина у 15-17 років уже усвідомлює мету своїх дій і співвідносить їх із мотивами фізичного самовдосконалення [3, 19]. Починаючи заняття спортом у цьому віці, юнаки спрямовують свою діяльність не на високий спортивний результат, а більшою мірою на оздоровлення організму та вдосконалення фігури.

Так, після проведення ранжування інтересів дівчат 5-11 класів до занять спортом було виявлено, що $75 \%$ п'ятикласниць займаються спортивно-оздоровчою діяльністю в позанавчальний час. Вони обрали такі види спорту: плавання, волейбол, різновиди фітнесу. Але з $25 \%$ дівчат, які не займаються спортом, 17 \% мають бажання відвідувати спортивні секції, здебільшого - заняття різновидами фітнесу. У 6-му класі відсоток школярок, які займаються спортивною діяльністю, знизився до 70,5\%, а серед дівчат, які навчаються у 7-му класі, - до $33,3 \%$.

Отже, можемо констатувати, що 3 5-го по 7-й класи у дівчат також виявлено певне зниження інтересу до занять спортом, як і в хлопців цього віку. Далі просте- жуємо позитивну динаміку: з 8-го по 11-й класи підвищується відсоток школярок, які займаються фізкультурно-спортивною діяльністю з $42 \%$ до $53 \%$ [22].

Таким чином, в ході дослідження визначено періоди зниження і підвищення мотивації підлітків до занять спеціальноорганізованою руховою активністю: в юнаків зниження мотивації простежується з 7-го до 8-го класу, а підвищення - 3 9-го до 11-го класу; у дівчат період зниження мотивації припадає на 7-ий та 10ий класи, а підвищення - на 11-й клас.

На питання «3 якою метою Ви б займалися фізичними вправами?» ми отримали результати, які представлено в таблиці № 1 . 3'ясовано, що вже в молодшому шкільному віці відповіді школярів різної статі суттєво відмінні. Це підтверджує науково доведений факт, що рухова активність хлопців віком 10-11 років вища, ніж у дівчат [18, 22], а період 1517 років дослідники вважають складним віком та пов'язують його зі статевим дозріванням. Тому пріоритетні мотиви респондентів щодо занять фізичними вправами є різними як у віковому аспекті, так і в статевому. Під час групування мотивів відвідування уроків фізичної культури, які обрали респонденти, ми встановили мотиваційні пріоритети до занять фізичною культурою юнаків і дівчат, які спрямовані на вдосконалення зовнішнього вигляду та фігури. Їхні бажання займатися фізичною культурою і спортом більшою мірою пов'язані 3 мотивацією вдосконалення форм тіла. Починаючи заняття спортом у віці 15-17 років, юнаки спрямовують свою діяльність не на високий спортивний результат, а переважно на оздоровлення організму та вдосконалення фігури. При зростанні та фізіологічній перебудові організму у підлітків може виникнути почуття тривоги, заниження самооцінки. I це не 


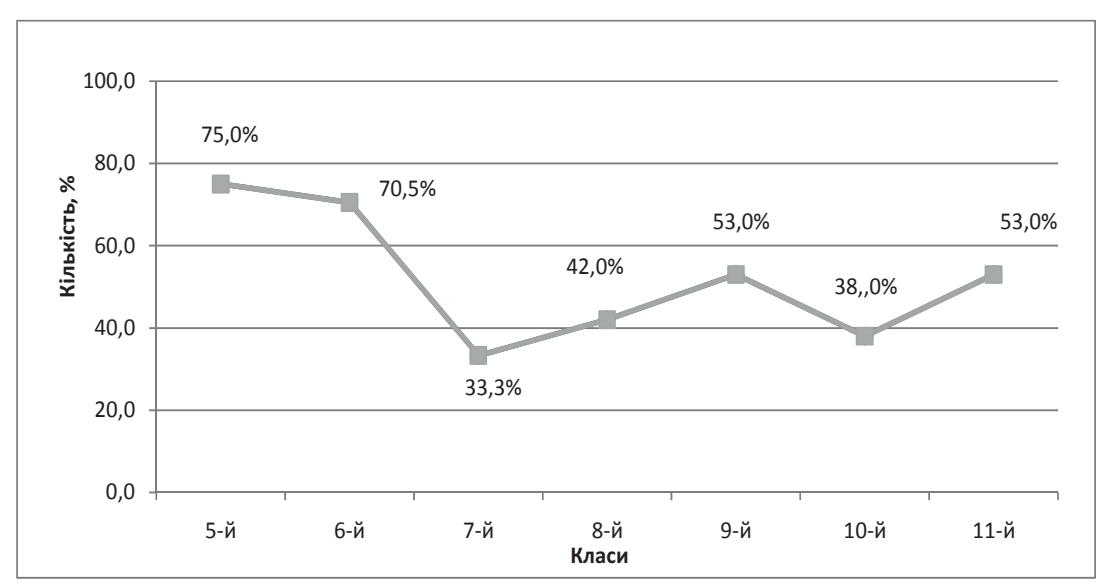

Рис. 2. Кількість учнів 5-11 класів, які займаються спортивно-оздоровчою діяльністю (дівчата), \%

випадково, бо в період статевого дозрівання відбувається інтенсивний ріст, збільшується обмін речовин, посилюють роботу залози внутрішньої секреції $[18,22]$.

Аналіз мотивів щодо занять фізичними вправами, визначених спортсменами, свідчить про те, що діяльність людини може впливати на формування мотивів, які визначають орієнтацію підлітка на професіоналізацію у сфері фізичної культури і спорту. Така позиція знаходить своє підтвердження у виявлені мотивів, що визначили юнаки, які займаються спортом. Спортсмени прагнуть до переваги над іншими, і це їх ще більше мотивує до занять спортом. Різниця в мотивації до занять фізичними вправами очевидна: у юнаків старших класів на першому місці - «удосконалення форми тіла», а в спортсменів - «досягнення високого спортивного результату».

Для визначення соціальних та особистісних потреб школярів у руховій активності ми визначали відмінності у мотивах юнаків

Мотиви школярів щодо занять фізичними вправами, \%

\begin{tabular}{|c|c|c|c|c|c|c|c|c|c|c|c|c|}
\hline \multirow[b]{2}{*}{ Клас } & \multirow[b]{2}{*}{ Стать } & \multirow[b]{2}{*}{$\mathrm{n}$} & \multicolumn{10}{|c|}{ Варіанти відповідей } \\
\hline & & & 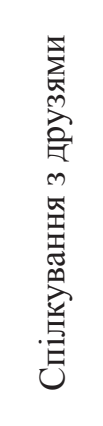 & 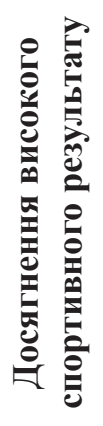 & 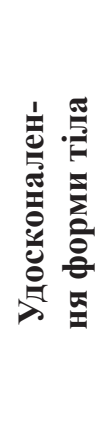 & 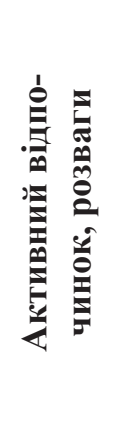 & 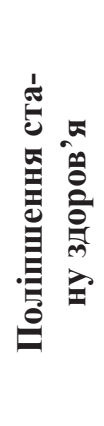 & 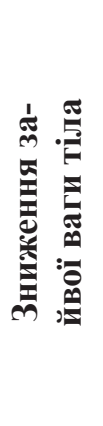 & 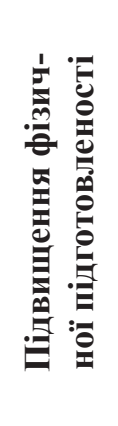 & 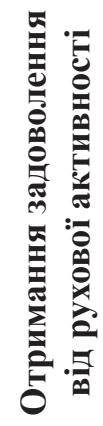 & 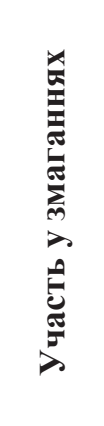 & 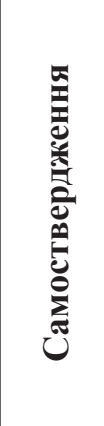 \\
\hline \multirow{2}{*}{5} & $\mathrm{x}$ & 21 & 28,6 & 4,8 & 38,1 & 14,0 & 19,0 & 0,0 & 9,5 & 14,3 & 52,4 & 38,1 \\
\hline & д & 53 & 39,6 & 32,1 & 35,8 & 17,0 & 32,1 & 17,0 & 15,1 & 7,5 & 20,8 & 20,8 \\
\hline \multirow{2}{*}{6} & $\mathrm{x}$ & 50 & 40,0 & 26,0 & 30,0 & 4,0 & 4,0 & 0,0 & 14,0 & 8,0 & 48,0 & 44,0 \\
\hline & д & 54 & 29,6 & 35,2 & 29,6 & 11,1 & 40,7 & 11,1 & 40,7 & 11,1 & 46,3 & 24,1 \\
\hline \multirow{2}{*}{7} & $\mathrm{x}$ & 34 & 52,9 & 26,5 & 0,0 & 47,1 & 0,00 & 0,0 & 41,2 & 32,4 & 32 & 14,7 \\
\hline & д & 39 & 66,7 & 7,7 & 33,3 & 25,6 & 7,7 & 33,3 & 17,9 & 25,6 & 7,7 & 0,0 \\
\hline \multirow{2}{*}{8} & $\mathrm{x}$ & 55 & 36,4 & 18,2 & 36,4 & 23,6 & 18,2 & 5,5 & 32,7 & 18,2 & 18,2 & 14,5 \\
\hline & д & 54 & 42,6 & 27,8 & 42,6 & 24,1 & 24,1 & 18,5 & 5,6 & 9,3 & 24,1 & 0,0 \\
\hline \multirow{2}{*}{9} & $\mathrm{x}$ & 90 & 32,65 & 34,69 & 32,65 & 22,45 & 28,57 & 6,12 & 22,2 & 14,4 & 14,4 & 28,9 \\
\hline & д & 5 & 30,00 & 12,7 & 49,1 & 27,3 & 50,0 & 23,33 & 7,3 & 3,6 & 7,3 & 10,9 \\
\hline \multirow{2}{*}{10} & $\mathrm{x}$ & 12 & 25,0 & 41,7 & 58,3 & 41,7 & 50,0 & 8,3 & 41,7 & 16,7 & 25,0 & 16,7 \\
\hline & д & 15 & 20,0 & 20,0 & 53,3 & 13,3 & 53,3 & 20,0 & 20,0 & 13,3 & 0,0 & 20,0 \\
\hline \multirow{2}{*}{11} & $\mathrm{x}$ & 41 & 34,15 & 46,34 & 51,22 & 21,95 & 39,02 & 21,95 & 43,90 & 21,95 & 26,83 & 26,83 \\
\hline & д & 65 & 10,77 & 18,46 & 76,92 & 29,23 & 55,38 & 30,8 & 33,85 & 21,54 & 12,31 & 20,00 \\
\hline
\end{tabular}


i дівчат різних вікових груп, які спонукають їх до занять руховою активністю (табл. 2). Перше місце у молодших юнаків займає вплив сімейного виховання - поради батьків. Далі цей показник поступово знижується, що пояснюється формуванням у підлітків прагненням до самостійності. Тому з віком на них більше впливає мікросередовище - поради друзів та 3МІ. У старшокласників визначено більш свідомий вибір - знання про користь занять фізичними вправами. На жаль, вчитель фізичної культури впливає на формування інтересу до рухової активності тільки у дівчат молодшої вікової групи. 3 віком у них спонукання змінюються. Уже у старших класах чинником, який спонукає дівчат до рухової активності, виявляється внутрішній фактор - «знання про користь за- нять фізичними вправами», який залежить від освітнього рівня учнів. Прикметно, що його вплив зростає $з$ віком.

Для уточнення факторів, які впливають на формування мотивації школярів до рухової активності, ми порушили питання про причини, що заважають їм займатися фізичною культурою i спортом. Серед головних було названо такі: брак вільного часу, неспроможність батьків оплачувати спортивні заняття, відсутність цікавих спортивно-оздоровчих груп, відсутність друзів, 3 якими можна відвідувати тренування.

Процес становлення особистості завжди дуже складний, багатофакторний i суперечливий. Він включає в себе безліч компонентів, взаємин, мотивів. Це тривалий процес, який завжди пов'язаний із конкретними умовами, в яких існує людина, 3 особливостями іiі спілкування, пізнання і діяльності. При цьому дуже важливо, яку роль в цьому процесі відіграє сама людина. Адже для успішного свого існування вона має бути суб'єктом свого життєвого конструювання. Ні для кого не секрет, що людина - соціальна істота. Отже, від того, яким чином вона навчиться взаємодіяти $з$ іншими, буде залежати те, наскільки успішним буде iii життєвий шлях загалом. Особистісні якості, що розвиваються у людини в онтогенезі, проявляються лише у взаємодії з соціумом [Постовий].

Ураховуючи результати нашого дослідження, слід зауважити: особливість фізичного виховання полягає в тому, що головні умови онтогенезу психіки людини та іiі фізичного розвитку при залучен-

Таблицяя 2

Фактори, які спонукають учнів до занять фізичними вправами, $(\mathrm{n}=638), \%$

\begin{tabular}{|c|c|c|c|c|c|c|c|c|c|c|}
\hline \multirow[b]{2}{*}{ Клас } & \multirow[b]{2}{*}{ Стать } & \multirow[b]{2}{*}{$\mathrm{n}$} & \multicolumn{8}{|c|}{ Варіанти відповідей } \\
\hline & & & 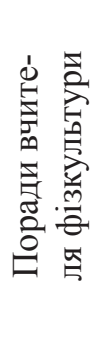 & 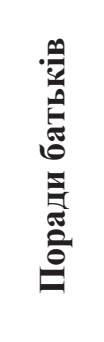 & 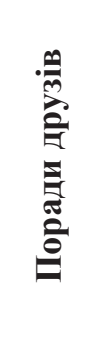 & 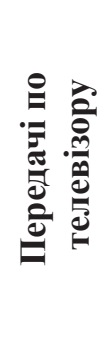 & 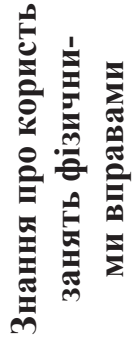 & 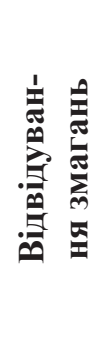 & 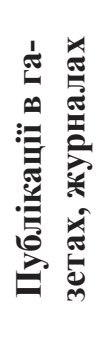 & 䍘 \\
\hline \multirow{2}{*}{5} & $x$ & 21 & 14,3 & 71,4 & 19,0 & 47,6 & 14,3 & 14,3 & 0,0 & 0,0 \\
\hline & д & 53 & 11,3 & 39,6 & 20,8 & 50,9 & 15,1 & 0,0 & 28,3 & 0,0 \\
\hline \multirow{2}{*}{6} & $\mathrm{x}$ & 50 & 34,0 & 60,0 & 18,0 & 30,0 & 4,0 & 18,0 & 14,0 & 0,0 \\
\hline & д & 54 & 5,6 & 24,1 & 29,6 & 64,8 & 18,5 & 35,2 & 40,7 & 0,0 \\
\hline \multirow{2}{*}{7} & $\mathrm{x}$ & 34 & 26,5 & 14,7 & 52,9 & 52,9 & 5,9 & 20,6 & 20,6 & 0,0 \\
\hline & д & 39 & 7,7 & 7,7 & 41,0 & 82,1 & 0,0 & 7,7 & 33,3 & 0,0 \\
\hline \multirow{2}{*}{8} & $x$ & 55 & 23,6 & 23,6 & 32,7 & 32,7 & 9,1 & 9,1 & 5,5 & 9,1 \\
\hline & д & 54 & 14,8 & 18,5 & 27,8 & 61,1 & 14,8 & 9,3 & 38,9 & 9,3 \\
\hline \multirow{2}{*}{9} & ю & 90 & 14,4 & 24,4 & 31,1 & 53,3 & 7,8 & 14,4 & 2,2 & 14,4 \\
\hline & д & 55 & 12,7 & 20,0 & 23,6 & 47,3 & 0,0 & 0,0 & 0,0 & 20,0 \\
\hline \multirow{2}{*}{10} & $x$ & 12 & 8,3 & 8,3 & 8,3 & 25,0 & 58,3 & 0,0 & 0,0 & 16,7 \\
\hline & д & 15 & 13,3 & 26,7 & 20,00 & 53,3 & 33,3 & 6,7 & 0,0 & 13,3 \\
\hline \multirow{2}{*}{11} & $\mathrm{x}$ & 41 & 7,32 & 21,95 & 21,95 & 43,90 & 21,95 & 12,20 & 0,0 & 12,20 \\
\hline & д & 65 & 7,69 & 20,00 & 20,00 & 30,77 & 35,4 & 6,15 & 3,1 & 9,23 \\
\hline
\end{tabular}

(C) Круцевич Т., Марченко О.,

Холодова О., 2021 
ні до цінностей фізичної культури мають бути єдиним процесом, а взаємодія цих умов здійснюватися завдяки власній активності індивіда

Для визначення емпатійного потенціалу особистості юнаків i дівчат ми використовуємо методику I.M. Юсупова, який експериментально встановив, що в онтогенезі особистості емпатійний потенціал має схильність як до спонтанної динаміки, так і до довільної регуляції, а його посилення пов'язане із загальним особистісним ростом і формуванням соціального інтелекту. Запропонована методика успішно досліджує емпатії (співпереживання), тобто вміння поставити себе на місце іншої людини і здатності довільної емоційної чуйності щодо переживання інших людей [30].

Опитувальник містить 6 діагностичних шкал емпатії, які виражають ставлення до батьків, тварин, людей похилого віку, дітей, героїв художніх творів, знайомих і незнайомців. Опитувальник складається 336 тверджень. Відповідаючи на кожне 3 них, респондент має оцінити, настільки він погоджується або не погоджується 3 даним твердженням, використовуючи 6 варіантів відповідей: «не знаю» - 0, «ні, ніколи» - 1 «іноді» - 2, «часто» - 3, «майже завжди» - 4, «так, завжди» - 5. За результатами до- слідження встановлюється загальний рівень емпатії хлопців і дівчат різних вікових груп.

Отже, результати порівняльного аналізу особливостей прояву емпатії школярів різних вікових груп свідчать також і про певні статеві відмінності та особливості їх загального емоційного фону.

Систематизовані дані щодо визначення загального рівня полікомунікативної емпатії (табл. 3) засвідчують, що середній (нормальний) рівень емпатії значно переважає над іншими рівнями у респондентів усіх вікових груп. Даний рівень емпатії говорить про те, що такі люди у спілкуванні уважні, намагаються зрозуміти більше, ніж сказано словами, однак за надмірних проявів почуттів втрачають терпіння.

Узагальнені дані таблиці 3 засвідчують, що у віковій групі 1113 років хлопці та дівчата у переважній кількості (73,3\% та 79,85\% відповідно) мають середній (нормальний) та високий (13,3\% та 14,18 \% відповідно) рівні полікомунікативної емпатії. Високий рівень емпатії мають більше дівчат, ніж хлопців: 14, 18\% - у віковй групі $11-13$ років; 15,6 \% у 14-15 років; 15,0 \% - у 16-17 років.

Слід зазначити, що відсоток школярок, які мають високий рівень емпатії з віком зростає, а юнаків - знижується ( 3 13,33 \% до 3,77 \%). Серед школярів 14-
15 років із високим рівнем емпатії дівчат виявилося більше, ніж хлопців (15,60\% та 11,72 \% відповідно). Привертає увагу те, що серед старшокласників, які мають високий загальний рівень емпатії, дівчат виявилося майже вчетверо більше, ніж юнаків $(3,77 \%$ та 15,00 \% відповідно).

Звертаємо увагу на збільшення кількості юнаків дівчат 14-15 років із низьким рівнем емпатії. Хлопців із низьким рівнем емпатії майже на $9 \%$ більше, ніж дівчат $(15,86 \%$ та 8,26 \% відповідно). У 16-17 років низький рівень емпатії мають вже 20, 75 \% юнаків, що на $15 \%$ більше, ніж дівчата (20,7 \% та 5,0 \% відповідно). Різке зниження рівня емпатії у даному віці може пояснювати прояв агресивності до однолітків (булінг) та дорослих (конфлікти).

Для визначення впливу фізичної культури і спорту на прояв емпатії у школярів різних вікових груп ми провели порівняльний аналіз періодів зниження та підвищення інтересу до занять спортом із рівнями прояву емпатіі.

Отже, у юнаків простежується період зниження рухової активності та занять спортом з 7-го до 8-го класу, а прояв емпатії в цьому віці має середній та високий рівні. Період підвищення рухової активності у хлопців простежується з 9-го до 11-го класу, натомість, прояв емпатії знижується

Загальний рівень емпатії школярів $(\mathrm{n}=638)$, \%

Таблиияя 3

\begin{tabular}{|c|c|c|c|c|c|c|c|c|c|c|c|c|}
\hline \multirow{4}{*}{ Рівні емпатії } & \multicolumn{12}{|c|}{ Вікова група } \\
\hline & \multicolumn{4}{|c|}{ 11-13 років } & \multicolumn{4}{|c|}{ 14-15 років } & \multicolumn{4}{|c|}{ 16-17 років } \\
\hline & \multicolumn{2}{|c|}{ Хлопці } & \multicolumn{2}{|c|}{ Дівчата } & \multicolumn{2}{|c|}{ Хлопці } & \multicolumn{2}{|c|}{ Дівчата } & \multicolumn{2}{|c|}{ Хлопці } & \multicolumn{2}{|c|}{ Дівчата } \\
\hline & $\mathrm{n}=105$ & $\%$ & $n=146$ & $\%$ & $n=145$ & $\%$ & $n=109$ & $\%$ & $n=53$ & $\%$ & $\mathrm{n}=80$ & $\%$ \\
\hline дуже високий & 0 & 0,00 & 3 & 2,24 & 3 & 2,07 & 0 & 0,00 & 0 & 0,00 & 0 & 0,00 \\
\hline високий & 14 & 13,33 & 19 & 14,18 & 17 & 11,72 & 17 & 15,60 & 2 & 3,77 & 12 & 15,00 \\
\hline середній & 77 & 73,33 & 107 & 79,85 & 102 & 70,34 & 83 & 76,15 & 40 & 75,47 & 64 & 80,00 \\
\hline низький & 14 & 13,33 & 5 & 3,73 & 23 & 15,86 & 9 & 8,26 & 11 & 20,75 & 4 & 5,00 \\
\hline дуже низький & 0 & 0,00 & 0 & 0,00 & 0 & 0,00 & 0 & 0,00 & 0 & 0,00 & 0 & 0,00 \\
\hline
\end{tabular}


3 віком.

У дівчат в період зниження рухової активності, який припадає на 7-ий та 10-ий класи, прояв емпатії нижчий, ніж у період підвищення рухової активності та занять спортом (11-й клас).

Також, ми провели окремий аналіз результатів тестування школярів, які займаються спортом. Виявлено, що спортсмени у своїй більшості мають середній рівень загальної емпатії (табл. 4). Утім, кількість осіб із високим рівнем емпатії серед дівчатспортсменок у 14-15 років на 12,7 \% вища, ніж у загальної кількості дівчат даної вікової категорії.

Середній рівень емпатії в юнаків і дівчат 14-15 років, які займаються спортом, приблизно однаковий (відповідно 74,19 \% i 71,43 \%). Проте, з віком дівчатаспортсменки стають більш емпатійними, на відміну від юнаків. Тобто показник загальної емпатії у них стає вищим на понад $10 \%$. Також серед дівчат, які займаються спортивною діяльністю, не виявлено осіб із низьким рівнем емпатії, натомість кількість юнаків із низьким рівнем емпатії з віком зросла на 7 \% (з 12,9\% до 20, 0 \%). Отримані результати дослідження свідчать про те, що заняття спортом впливають на формування у дівчат не тільки лідерських та вольових якостей особистості, а і на співчуття, ба- жання допомоги, великодушність та чуйність.

Отримані дані щодо низького рівня емпатії хлопців знаходять своє підтвердження у виявлені мотивів, що визначили хлопці i юнаки, які займаються спортом. «Досягнення високого спортивного результату», «участь у змаганнях» та «підвищення фізичної підготовленості» - мотиви, які доводять, що юнаки-спортсмени отримують задоволення від занять спортом, прагнуть до переваги над іншими, що більше мотивує їх до занять спортом. Це природно, бо специфіка спорту полягає в перемозі над суперником, що є невід'ємним складником перемоги у змаганнях.

Також за експрес-діагностикою емпатії нами були виділені й описані такі показники емпатичної спрямованості, як емпатія до батьків, тварин, пристарілих людей, дітей, героїв літературних творів, незнайомців. Попри високі показники надійності, валідності та дискримінативності експрес-діагностики емпатії, значущим та важливим виявився акцент саме на показниках за окремими шкалами тесту, оскільки в даних показниках емпатії більшою мірою розкривається рівень емпатії особистості школярів різних вікових груп.

Так, розглядаючи рівень емпатії до батьків, у значної кількості респондентів виявлено високий та дуже високий рівень. Згідно 3 даними нашого дослідження, турбота про батьків найбільше проявляється у респондентів середнього та старшого шкільного віку. Частка юнаків цього віку із рівнем «високий» та «дуже високий» складає 39,58 \% від їх загальної кількості, серед дівчат - 44,19 \%, що інформує про можливе постійне занепокоєння за рідних і близьких людей.

Однією із головних особливостей підліткового та раннього юнацького віку є зміна значущих осіб та перебудова міжособистісної взаємодії з дорослими. яка хоча i $\epsilon$ значущою для юнака, але не передбачає повного саморозкриття. Тому, не дивлячись на високу емпатію до батьків, визначаючи фактори, які спонукають хлопців і дівчат до занять фізичними вправами, виявлено, що з віком вплив батьків на прийняття рішень зменшується з $71 \%$ до $22 \%$, а у дівчат - $340 \%$ до $20 \%$.

Розподіл респондентів за рівнем емпатії до тварин виявив, що серед юнаків всіх вікових груп більше, ніж серед дівчат, осіб із низьким рівнем емоційної прихильності до тварин, що свідчить, про властивість дівчат більше співчувати та допомагати тваринам.

Дискусія. Вивченням емпатії до недавнього часу переважно

\section{Загальний рівень емпатії школярів, які займаються спортом, $(\mathrm{n}=126), \%$}

\begin{tabular}{|c|c|c|c|c|c|c|c|c|}
\hline \multirow{4}{*}{ Рівні емпатії } & \multicolumn{8}{|c|}{ Вікова група } \\
\hline & \multicolumn{4}{|c|}{ 14-15 років } & \multicolumn{4}{|c|}{ 16-17 років } \\
\hline & \multicolumn{2}{|c|}{ Хлопці } & \multicolumn{2}{|c|}{ Дівчата } & \multicolumn{2}{|c|}{ Хлопці } & \multicolumn{2}{|c|}{ Дівчата } \\
\hline & $\mathrm{n}=46$ & $\%$ & $\mathrm{n}=12$ & $\%$ & $\mathrm{n}=51$ & $\%$ & $\mathrm{n}=17$ & $\%$ \\
\hline дуже високий & 0 & 0,00 & 0 & 0,00 & 0 & 0,00 & 0 & 0,00 \\
\hline високий & 6 & 13,04 & 3 & 25,00 & 1 & 1,96 & 2 & 11,76 \\
\hline середній & 34 & 73,91 & 9 & 75,00 & 40 & 78,43 & 15 & 88,24 \\
\hline низький & 6 & 13,04 & 0 & 0,00 & 10 & 19,61 & 0 & 0,00 \\
\hline дуже низький & 0 & 0,00 & 0 & 0,00 & 0 & 0,00 & 0 & 0,00 \\
\hline
\end{tabular}

(C) Круцевич Т., Марченко О., Холодова О., 2021 
займались дослідники соціальної психології, педагогики та психотерапії. В останні роки дослідження феномену емпатії стає актуальним для різних наукових напрямів, в тому числі і напряму фізичної культури і спорту.

Вважаючи емпатію важливим чинником індивідуального та професійного розвитку особистості, вчені наголошують на іiі суттєвий вплив, як соціально-психологічного феномену, на особистість в цілому, підвищуючи мотивацію, продуктивність та ефективність діяльності людини. [4]. Психологи стверджують, що людина, яка має високий рівень емпатії, більш чутлива до проблем і потреб оточення, великодушна, схильна багато що пробачати, емоційно чуйна. Вона постійно потребує соціального схвалення своїх дій $[3,6,25]$. Для людей із низьким рівнем емпатії характерною рисою $є$ раціоналізм. Вони схильні уникати емоційних проявів,у прийнятті рішень керуються здоровим глуздом та аргументами, перевагу віддають усамітненим заняттям конкретними справами,уникають надто емоційних людей, установлюючи контакти з оточенням, - зазнають певних труднощів $[3,5,8]$.

Саїнчук М. М. зауважує, що для фізкультурно-спортивної галузі наукознавства «емпатійна» проблематика є чужою і цьому $є$ раціональне пояснення - тривале домінування спортизованої парадигми фізичної культури, яка породила специфічні гуманітарні проблеми і навіть кризу. У рамках цієї парадигми фізичної культури культивуються не стільки співчуття чи співпереживання, скільки перемога, незламні риси характеру тощо. Такі антиемпатійні риси можуть бути цілком прийнятними для спорту [28]. Дані доводи підтверджують результати нашого дослідженння. Подібної думки дотримуються Федорова О.В., Фомінова О.М., Косенко Т.Ю. [8]. Вчені стверджують, що в умовах змагань висока емпатія може надавати негативну дію на результат баскетболістів, які не уміють регулювати свій емоційний стан. Також, спортсменові 3 високим рівнем прояву емпатії може знадобитися спеціальна допомога, особливо для регуляції його емоційних проявів і використання їх в потрібному напрямі [8].

Вчені стверджують, що успішне виконання завдань фізичної підготовки і спортивного тренування, навчання, виховання й управління зумовлюється вмінням опертися на положення індивідуального підходу, що полягають у знанні індивідуальних особливостей особистості учня [8].

Психологи зауважують, що саме в дослідженнях, які проводяться в підлітковому та юнацькому середовищі, вперше починають виявлятися статеві відмінності у ставленні до різних об'єктів емпатії. Дівчата загалом демонструють більшу міру співчуття до тварин, ніж хлопці. Цей факт можна вважати результатом раннього засвоєння дівчатами етичних норм, а також більшою їхньою орієнтацією на спілкування, прагненням мати визнання в міжособистісних стосунках, тоді як хлопці більш орієнтовані на наочні досягнення. Подібні відмінності I.M. Юсупов пояснює особливостями соціалізації дівчат, що виявляються в них у конформності та пошуку соціального схвалення [30]. Результати нашого дослідження також доводять, що у дівчат всіх вікових груп виявлено вищий рівень емпатії ніж у хлопців.

Наомі Айзенберг, провідна дослідниця соціальної нейробіології в Каліфорнійському університеті в Лос-Анджелесі, також вважає, що дівчата у віці від 14 до 17 років більше, ніж хлопціровесники, переймаються турботою та співчуттям, емпатія в них розвивається раніше. На її думку, це пов'язано зі зростанням темпів дозрівання дівчат. Юнаки досягають такого рівня лише після 15-16 років [2.].

Р. Крайг зосереджує увагу на тому, що емпатія грунтується на соціальному висновку: «Якщо ви не знаєте того, що відчуває інша людина, ви не зможете їй співчувати» [12]. Дані зарубіжних досліджень, спрямованих на вивчення емпатії підлітків та юнаків, свідчать про глибокі зв'язки між емпатійністю та етичною поведінкою. Етичні норми, засвоєні на ранніх етапах вікового розвитку, починають виявлятися у вчинках і думках. Високо емпатійні діти в міжособистісній взаємодії власні невдачі схильні пояснювати внутрішніми причинами, тоді як діти 3 низькими показниками емпатії дають їм екстремальну оцінку $[7,8]$. Дослідження вітчизняних науковців також засвідчують про вплив прояву емпатії підлітка на якість та ефективність взаємодії між ним і викладачем, що є одним із ключових факторів у формуванні мотивації до фізичного вдосконалення та цінностей фізичної культури і спорту [19]. Також ми згодні зі слушною думкою науковців, про те, що особистісні показники стають важливими в практичній діяльності лише в тому випадку, якщо вони враховуються в контексті всієї програми тестування разом із результатами об'єктивних спостережень та інших тестів [8]. Тому емпатійну спрямованість юнаків і дівчат на даному етапі дослідження ми не розглядаємо в контексті морального або етичного аспектів, а розуміємо як певний прояв емпатії в деяких сферах життєдіяльності людини. Це надало нам змогу виявити прояв індивідуальних особливостей емпатії юнаків і дівчат, які займаються та не займаються спортивною діяльністю в різні вікові періоди.

Ми згодні 3 думкою Саїнчука М.М. про те, що визначення рівня емпатії можна використовувати у сфері фізичної культури i спорту як індикатор придатності до професії (при відборі), а та-

(C) Круцевич Т., Марченко О., Холодова О., 2021 
кож як джерело інформації щодо готовності майбутніх спеціалістів до ефективної професійної діяльності. Однак, як стверджує науковець, подібне можна реалізувати лише при розробці специфічних і адаптованих до професії «емпатійних опитувальників». Тобто, емпатія в освітній і фізкультурно-спортивній сферах може бути складовою як психограми, так i професіограми [28].

Висновки. 3 огляду на означене, ми можемо зробити наступні висновки.

Аналіз мотивів щодо занять фізичними вправами, визначених школярами, що не займаються спортом і спортсменами, свідчить про те, що діяльність людини може впливати на формування мотивів, які визначають орієнтацію підлітка на професіоналізацію у сфері фізичної культури i спорту. Спортсмени прагнуть до переваги над іншими, i це їх ще більше мотивує до занять спор- том. Різниця в мотивації до занять фізичними вправами очевидна: у юнаків старших класів на першому місці - «удосконалення форми тіла», а в спортсменів - «досягнення високого спортивного результату».

За результатами емпіричного дослідження особливостей полікомунікативної емпатії школярів різних вікових груп виявлено певні статеві відмінності та вікові особливості їх загального емоційного фону. Встановлено, що юнаки всіх вікових груп є менш емпатійними, ніж дівчата, високий рівень загальної емпатії мають більше дівчат, ніж юнаків.

Заняття фізичною культурою і спортом мають певний вплив на рівень формування емпатії особистості, про що свідчать отримані нами у перебігу дослідження результати. Середній рівень емпатії в юнаків і дівчат 14-15 років, які займаються спортом, приблизно однаковий (відповідно 74,19 \% і 71,43 \%). Проте з віком дівчатаспортсменки стають більш емпатійними, на відміну від юнаків, у них не виявлено осіб з низьким рівнем емпатії, натомість у юнаків-спортсменів показник загальної емпатії з віком знижується. Низький рівень емпатії хлопців знаходить своє підтвердження у виявлені мотивів, що визначили хлопці та юнаки, які займаються спортом, бо специфіка спорту полягає в перемозі над суперником, що є невід’ємним складником перемоги у змаганнях.

Перспективи дослідження. У результаті проведеного дослідження ми отримали досить великий обсяг необхідних знань, що надає нам можливість розробки моделі компонентів індивідуальної фізичної культури підлітків і молоді $з$ критеріями оцінки для різних вікових і статевих груп.

Конфлікт інтересів. Автори заявляють, що не існує ніякого конфлікту інтересів.

\section{Література}

1. Андріученко Т. Формування здорового способу життя. Навчально-методичні рекомендації / Авт. колект. Т. Андріученко, О. Вакуленко, В. Волков, Н. Дзюба, В. Коляда, Н. Комарова, І. Пєша, Н. Тілікіна (кер. авт. колект. О. Вакуленко). - К.: ДУ «Державний інститут сімейної та молодіжної політики», 2018. - 100 с. Арканцева ТА. Отношение родителей и детей в гендерном измерении: учеб. пособ. Москва: НОУ ВПО Московский психолого-социальный ин-т; 2011. $70 \mathrm{c}$.

2. Аршавський И.А. Основы возрастной периодизации. В: Возрастная физиология. Ленинград: Наука; 1975. с. 5-67

3. Варій М.Й. Загальна психологія: навч. посіб. Київ: Центр учбової літ.; 2007. 968 с.

4. Вавринів О.С. Соціально-психологічні особливості формування професійної емпатії майбутніх рятувальників. Дисертація кандидата психологічних наук, Сєвєродонецьк - 2020, 265 с.

5. Безверхня Г., Маєвський М. Рівень емпатії та образ фізично культурної людини у студенток педагогічних спеціальностей // Спортивний вісник Придніпров'я. - 2015. - № 1. - С. 10-14.,

6. Бендас Т.В. Гендерная психология : учебное

\section{References}

1. Andriuchenko T. Formuvannia zdorovoho sposobu zhyttia. Navchalno-metodychni rekomendatsii / Avt. kolekt. T. Andriuchenko, O. Vakulenko, V. Volkov, N. Dziuba, V. Koliada, N. Komarova, I. Piesha, N. Tilikina (ker. avt. kolekt. O. Vakulenko). - K.: DU «Derzhavnyi instytut simeinoi ta molodizhnoi polityky», 2018. - 100 sArkantseva TA. Otnoshenye rodytelei y detei $\mathrm{v}$ hendernom yzmerenyy: ucheb. posob. Moskva: NOU VPO Moskovskyi psykholoho-sotsyalnыi yn-t; 2011. 70 s.

2. Arshavskyi YA. Osnovы vozrastnoi peryodyzatsyy. V: Vozrastnaia fyzyolohyia. Lenynhrad: Nauka; 1975. s. 5-67

3. Varii MI. Zahalna psykholohiia: navch. posib. Kyiv:Tsentr uchbovoi lit.;2007. 968 c.

4. Vavryniv O.S. Sotsialno-psykholohichni osoblyvosti formuvannia profesiinoi empatii maibutnikh riatuvalnykivysertatsiia kandydata psykholohichnykh nauk, Sievierodonetsk - 2020, 265 s.

5. Bezverkhnia H., Maievskyi M. Riven empatii ta obraz fizychno kulturnoi liudyny u studentok pedahohichnykh spetsialnostei // Sportyvnyi visnyk Prydniprovia. - 2015. - \# 1. - S. 10-14.,

6. Savchenko V. H., Hura E. I. Empatiia v protsesi profesiinoi adaptatsii studentiv vyshchykh navchal-

(C) Круцевич Т., Марченко О.,

Холодова О., 2021 
пособие. Санкт-Петербург: Питер Пресс; 2009. $428 \mathrm{c}$.

7. Журавльов А.Л. Соціально-психологічні проблеми управління - М. : Наука, 1983. - 220с. Крайг Г. Психологі розвитку : Пер. 3 анг.Спб.: Пітер, 2000. - 992 c.

8. Журавльова Л.П. Психологічні основи розвитку емпатії людини [автореферат]. Одеса: Південноукр. держ. пед. ун-т ім. К. Д. Ушинського; 2008. $48 \mathrm{c}$

9. Ильин Е.П. Психология спорта. СанктПетербург: Питер; 2008. 352 с

10. Ільченко О. Гендерний підхід як нова методологія наукових досліджень в галузі педагогіки: генеза розвитку. Педагогічні науки: зб. наук. пр. Полтава; 2011. с. 22-9.

11. Коломієць Т.В. Особливості емпатійної міжособистістої взаємодії в юнацькому віці [дисертація]. Житомир: Житомирський нац. агроекологічний ун-т; 2015. 197 с.

12. Крайг Г. Психология развития. Санкт-Петербург: Питер; 2000. 988 с.

13. Круцевич Т.Ю., Марченко О.Ю.. Гендерні відмінності ієрархічної структури ціннісних орієнтацій школярів різних вікових груп. Фізичне виховання, спорт і культура здоров'я у сучасному суспільстві. 2018;3(43):144.

14. Круцевич Т.Ю, редактор. Теорія і методика фізичного виховання: підруч. для студ. вищ. навч. закл. фіз. виховання і спорту. Т. 2. Київ: Олімпійська літ.; 2017. 392 с.

15. Круцевич Т.Ю, Марченко О.Ю. Концептуальні засади гендерного підходу у фізичному вихованні школярів. Спортивний вісник Придніпров'я: науково-практичний журнал. 2019; 2:104-114.

16. Кордуэлл М. Психология А-Я: словарь-справочник. Москва: Фаир-Пресс; 2000. 448 с.

17. Леонтьев А.Н. Деятельность и личность. Психология личности. Т. 2. Самара: Изд. дом Бахpax; 1999. c. 165-88.

18. Марченко О.Ю. Теоретико-методологічні основи гендерного підходу до формування аксіологічної значущості фізичної культури школярів: [дисертація]. Київ: Національний університет фізичного виховання і спорту України; 2019. $590 \mathrm{c}$.

19. Марченко О.Ю. Особливості прояву емпатії школярів різних вікових груп у гендерному вимірі. Фізична культура, спорт та здоров'я нації. 2018;6(25):67

20. Москаленко Н, Єлісєєва Д. Вплив самостійних занять фізичним вихованням на фізичний стан старшокласників. Спортивний вісник Придніпров'я. 2017;(1):197-202.

21. Москаленко Н.В, Решетилова В., Михайленко Ю. Сучасні підходи щодо підвищення рухо- nykh zakladiv fizychnoi kultury i sportu // Slobozhanskyi naukovo-sportyvnyi visnyk. - 2013. - \#1. - S. 87-90Bendas TV. Hendernaia psykholohyia : uchebnoe posobye. Sankt-Peterburh: Pyter Press; 2009. 428 s.

7. Zhuravlov A.L. Sotsialno-psykholohichni problemy upravlinnia - M. : Nauka, 1983. - 220s.Kraih H. Psykholohi rozvytku : Per. Z anh.Spb.: Piter, 2000. - $992 \mathrm{~s}$.

8. Zhuravlova LP. Psykholohichni osnovy rozvytku empatii liudyny [avtoreferat]. Odesa: Pivdennoukr. derzh. ped. un-t im. K. D. Ushynskoho; 2008. 48 s

9. Ylyn EP. Psykholohyia sporta. Sankt-Peterburh: Pyter; 2008. $352 \mathrm{~s}$

10. Ilchenko O. Hendernyi pidkhid yak nova metodolohiia naukovykh doslidzhen v haluzi pedahohiky: geneza rozvytku. Pedahohichni nauky: zb. nauk. pr. Poltava; 2011. s. 22-9.

11. Kolomiiets TV. Osoblyvosti empatiinoi mizhosobystistoi vzaiemodii v yunatskomu vitsi [dysertatsiia]. Zhytomyr: Zhytomyrskyi nats. ahroekolohichnyi un-t; 2015. $197 \mathrm{~s}$.

12. Kraih H. Psykholohyia razvytyia. Sankt-Peterburh: Pyter; 2000. $988 \mathrm{~s}$.

13. Krutsevych TIu, Marchenko OIu. Henderni vidminnosti iierarkhichnoi struktury tsinnisnykh oriientatsii shkoliariv riznykh vikovykh hrup. Fizychne vykhovannia, sport i kultura zdorovia u suchasnomu suspilstvi. 2018;3(43):144.

14. Krutsevych TIu, redaktor. Teoriia i metodyka fizychnoho vykhovannia: pidruch. dlia stud. vyshch. navch. zakl. fiz. vykhovannia i sportu. T. 2. Kyiv: Olimpiiska lit.; 2017. $392 \mathrm{~s}$.

15. Krutsevych TIu, Marchenko OIu. Kontseptualni zasady hendernoho pidkhodu u fizychnomu vykhovanni shkoliariv. Sportyvnyi visnyk Prydniprovia: naukovo-praktychnyi zhurnal. 2019; 2:104114.

16. Korduэll M. Psykholohyia A-Ya: slovar-spravochnyk. Moskva: Fayr-Press; 2000. 448 s.

17. Leontev AN. Deiatelnost y lychnost. Psykholohyia lychnosty. T. 2. Samara: Yzd. dom Bakhrakh; 1999. s. $165-88$.

18. Marchenko OIu. Teoretyko-metodolohichni osnovy hendernoho pidkhodu do formuvannia aksiolohichnoi znachushchosti fizychnoi kultury shkoliariv: [dysertatsiia]. Kyiv: Natsionalnyi universytet fizychnoho vykhovannia i sportu Ukrainy; 2019. $590 \mathrm{~s}$.

19. Marchenko OIu. Osoblyvosti proiavu empatii shkoliariv riznykh vikovykh hrup u hendernomu vymiri. Fizychna kultura, sport ta zdorovia natsii. 2018;6(25):67

20. Moskalenko N, Yelisieieva D. Vplyv samostiinykh zaniat fizychnym vykhovanniam na fizychnyi stan starshoklasnykiv. Sportyvnyi visnyk Prydniprovia. 
вої активності дітей шкільного віку. Спортивний вісник Придніпров'я. 2018;(1):203-8.

22. Пангелова Н.С. Теоретико-методичні засади формування гармонійно розвиненої особистості дитини дошкільного віку в процесі фізичного виховання [дисертація]. Київ: Національний університет фізичного виховання і спорту України; 2014. 445 с.

23. Полуянов В.Б. Теория и практика маркетинга в управлении профессиональным образованием [автореферат]. Екатеринбург: Уральский гос. проф.-пед. ун-т; 2001.26 с.

24. Постовий В.Г. Тенденції і пріоритети виховання дітей в сучасній сім'ї. Київ: Ін-т проблем виховання АПН України; 2006. 190 с.

25. Рубинштейн С.Л. Основы общей психологи. Санкт-Петербург: Питер; 2000. 712 с.

26. Савченко В.Г., Гура Е.I. Емпатія в процесі професійної адаптації студентів вищих навчальних закладів фізичної культури і спорту // Слобожанський науково-спортивний вісник. - 2013. - №1. - С. 87-90.

27. Саїнчук М.М. Потреба суспільства в фізично досконалій особистості і бачення іiї старшокласниками // М. С. Саїнчук, М. М. Саїнчук // Педагогіка, психологія та медико-біологічні проблеми фізичного виховання і спорту. - 2012. - № 1. - C. $97-100$

28. Саїнчук М.М., Саїнчук А.М, Іванік О.Б., Саїнчук O.M., Емпатія як індикатор готовності студентів фізкультурно-спортивної галузі до майбутньої професійної діяльності, Науковий часопис НПУ імені М.П. Драгоманова Випуск 8 (102) 2018

29. Столяров В.И. Теория и методология современного физического воспитания: состояние разработки и авторская концепция. Киев: Олимпийская лит.; 2015. 704 с.

30. Юсупов І.М. Психологія емпатії (Теоретичні i прикладні аспекти). [диссертация]. СанктПетербург; 2001. 252 с.

31. Ciccomascolo LE., Sullivan E.C. (2013). The dimensions of physical education. Jones \& Bartlett learning. Burlington, MA

32. Magri E., Moran D. (Ed.) (2017) Empathy, Sociality, and Personhood. Essays on Edith Stein's Phenomenological Investigations. Springer International Publishing AG 14. Sezen-Balcikanli G. (2009) Fair play and empathy: A research study with student teachers. Journal of US-China Public., Volume 6, No.4 (Serial No.47). : 79-84

33. Crum B, Mester J. A critical review of competing PE concepts. Sport scinces in Europe 1993 Current and future perspectives. Aachen: Meyer and Meyer; 1994. p. 516-33.

34. Krutsevych TY, Marchenko OY. Age differenced
2017;(1):197-202.

21. Moskalenko NV, Reshetylova V, Mykhailenko Yu. Suchasni pidkhody shchodo pidvyshchennia rukhovoi aktyvnosti ditei shkilnoho viku. Sportyvnyi visnyk Prydniprovia. 2018;(1):203-8.

22. Panhelova NIe. Teoretyko-metodychni zasady formuvannia harmoniino rozvynenoi osobystosti dytyny doshkilnoho viku v protsesi fizychnoho vykhovannia [dysertatsiia]. Kyiv: Natsionalnyi universytet fizychnoho vykhovannia i sportu Ukrainy; 2014. $445 \mathrm{~s}$.

23. Poluianov VB. Teoryia y praktyka marketynha v upravlenyy professyonalnыm obrazovanyem [avtoreferat]. Ekaterynburh: Uralskyi hos. prof.-ped. un-t; $2001.26 \mathrm{~s}$.

24. Postovyi VH. Tendentsii i priorytety vykhovannia ditei v suchasnii simi. Kyiv: In-t problem vykhovannia APN Ukrainy; 2006. 190 s.

25. Rubynshtein SL. Osnovы obshchei psykholohy. Sankt-Peterburh: Pyter; 2000. 712 s.

26. Savchenko V. H., Hura E. I. Empatiia v protsesi profesiinoi adaptatsii studentiv vyshchykh navchalnykh zakladiv fizychnoi kultury i sportu // Slobozhanskyi naukovo-sportyvnyi visnyk. - 2013. -\#1. - S. 87-90.

27. Sainchuk MM. Potreba suspilstva v fizychno doskonalii osobystosti i bachennia yii starshoklasnykamy // M. S. Sainchuk, M. M. Sainchuk // Pedahohika, psykholohiia ta medyko-biolohichni problemy fizychnoho vykhovannia i sportu. 2012. - \# 1. - S. 97-100

28. Sainchuk M. M., Sainchuk A.M, Ivanik O.B., Sainchuk O.M., Empatiia yak indykator hotovnosti studentiv fizkulturno-sportyvnoi haluzi do maibutnoi profesiinoi diialnosti, Naukovyi chasopys NPU imeni M.P. Drahomanova Vypusk 8 (102) 2018

29. Stoliarov VY. Teoryia y metodolohyia sovremennoho fyzycheskoho vospytanyia: sostoianye razrabotky y avtorskaia kontseptsyia. Kyev: Olympyiskaia lyt.; 2015. 704 s.

30. Yusupov IM. Psykholohiia empatii (Teoretychni i prykladni aspekty). [dyssertatsyia]. Sankt-Peterburh; 2001. $252 \mathrm{~s}$.

31. Ciccomascolo, L. E., Sullivan, E. C. (2013). The dimensions of physical education. Jones \& Bartlett learning. Burlington, MA

32. Magri E., Moran D. (Ed.) (2017) Empathy, Sociality, and Personhood. Essays on Edith Steins Phenomenological Investigations. Springer International Publishing AG 14. Sezen-Balcikanli G. (2009) Fair play and empathy: A research study with student teachers. Journal of US-China Public., Volume 6, No.4 (Serial No.47). : 79-84

33. Crum B, Mester J. A critical review of competing PE concepts. Sport scinces in Europe 1993 - Current and future perspectives. Aachen: Meyer and

(C) Круцевич Т., Марченко О.,

Холодова О., 2021 
of self-esteem of physical self at school. Gender aspects. Фізичне виховання, спорт і культура здоров'я у сучасному суспільстві. 2017;2(38):112-6.

35. Lavay, B., French, R., \& Henderson, H. (2015). Positive Behavior Management in Physical Activity Settings. USA: Human Kinetics

36. Sezen-Balcikanli G. (2009) Fair play and empathy: A research study with student teachers. Journal of US-China Public., Volume 6, No.4 (Serial No.47). : 79-84. 15.

37. Shields, L. L. D. \& Bredemier, L. J. B. (1994). Character development and physical activity. USA: Human Kinetics. 269 p
Meyer; 1994. r. 516-33.

34. Krutsevych TY, Marchenko OY. Age differenced of self-esteem of physical self at school. Gender aspects. Fizychne vykhovannia, sport i kultura zdorovia u suchasnomu suspilstvi. 2017;2(38):112-6.

35. Lavay, B., French, R., \& Henderson, H. (2015). Positive Behavior Management in Physical Activity Settings. USA: Human Kinetics

36. Sezen-Balcikanli G. (2009) Fair play and empathy: A research study with student teachers. Journal of US-China Public., Volume 6, No.4 (Serial No.47). : 79-84. 15.

37. Shields, L. L. D. \& Bredemier, L. J. B. (1994). Character development and physical activity. USA: Human Kinetics. 269 r

\section{Круцевич Тетяна Юріївна}

Національний університет фізичного виховання і спорту України вул. Фізкультури, 1, Київ, Україна, 03680

ORCID https://orcid.org/0000-0002-4901-6148

Марченко Оксана Юріївна

o.mar4enko17@gmail.com

тел. +38(098)6110300

Національний університет фізичного виховання і спорту України вул. Фізкультури, 1, Київ, Україна, 03680

ORCID https://orcid.org/ 0000-0002-2902-5960

Холодова Ольга Світозарівна

Національний університет фізичного виховання і спорту України вул. Фізкультури, 1, Київ, Україна, 03680 